\title{
Effective Use of E-Learning Technologies to Promote Student-Centered Learning Paradigms within Higher Education Institutions
}

\author{
Beatrice Aguti, Robert J Walters, Gary B Wills \\ Electronics and Computer Science, University of Southampton, \\ Hampshire, United Kingdom
}

\begin{abstract}
The unveiling of e-learning technologies has led to an increase in the use of e-learning systems also known as educational technologies to support blended learning in Universities by providing a mix of face-to-face classroom teaching, live e-learning, self-paced e-learning and distance learning. Despite the existing benefits of using e-learning, some higher education institutions have not utilized e-learning to its full potential to foster student-centered learning. This approach of learning is profoundly social and therefore emphasizes the influence of social environments that surround a student's learning and cognitive development. Student-centered learning focuses on fostering communicative and collaborative skills amongst the students as well as with their teachers making the students more engaged rather than passive in their learning process. E-learning technologies have the ability to support social-interactions between students and teachers and amongst students. However, there are limited studies that offer a comprehensive framework for effectively using e-learning systems to support student-centered learning in higher education institutions. It is therefore imperative that learning technologists understand the factors and approaches of influencing effective blended learning. Results of an expert survey conducted show a number of factors established as being important for enhancing student-centered learning by effectively using e-learning technologies. This paper describes a methodological framework consisting of factors necessary for fostering student-centered learning by effectively using e-learning technologies within Universities.
\end{abstract}

\section{Introduction}

In the wake of the $20^{\text {th }}$ Century, there has been a paradigm shift in learning within higher education institutions towards student-centered learning, a learning model that primarily underpins blended learning. Blended learning encompasses use of a mix of improved course delivery strategies during face-to-face classroom teaching with live e-learning, self-paced e-learning which are facilitated by Virtual Learning Environments (VLEs) [5]. In Mayes e-learning is defined as the use of technology to support and enhance learning practice. Consequently, the adoption of e-learning technologies has impacted on the planning, learning design, management and administration of the learning process and delivery of learning content to the students thereby promoting blended e-learning [11] [18].

In Rosenberg, the study shows that teachers and students prefer the blended learning approach, which is a mix of traditional face-to-face teaching with collaborative learning [15]. Student-centered learning requires the support of teachers to identify the appropriate blend of e-learning technologies to foster communication and collaborative learning amongst the students. In other words, student-centered learning enables students to develop communicative and collaborative skills through group work, allow students to direct their own learning, ask questions and complete tasks independently thereby encouraging active participation of students in their learning [7]. Student-centered learning can be promoted by supporting the teachers in identifying a perfect blend of desired content and learning outcomes. Through student-centered learning, students get to focus on student-led workshops and group projects which foster communication and collaborative skills. However, the crucial factor lies in supporting teachers to guide the students in understanding the diverse range of VLEs and effectively using them. VLEs include learning management systems such as Moodle, WebCT, and Blackboard as well Web 2.0 technologies which have become enablers for collaborative learning amongst students and lecturers, online discussions and distance learning.

Over $80 \%$ of Higher Education Institutions (HEIs) in the developed world are actively engaging in the 
use of e-learning systems for supporting their teaching and learning, with $97 \%$ of Universities reported to be using one or more forms of VLE [4]. On the other hand, Universities in developing countries especially sub-Saharan Africa are progressively adopting these e-learning technologies for teaching, research and supporting students' learning so as to reap the same benefits harnessed by the developed economies. However, education in sub-Saharan Africa are grappling with the continuing economic downturn, high demand for higher education in emerging knowledge-driven economies as well as inadequate availability of experienced and skilled teachers [20]. There is a need to improve on the quantity and quality of teachers in order to meet the high demand for education. Universities in subSaharan Africa are also still facing numerous challenges such as high volume of students, limited ICT infrastructure, high illiteracy levels, ineffective computer system maintenance and poor ICT support relative to the implementation of e-learning [19].

E-learning has grown to complement traditional classroom-based learning by combining the use of technology with effective pedagogy and reflective teaching thereby transforming higher education [3]. Besides, e-learning in higher education may be used as a resource to provide online student and instructor support, online student management, and provision of formative and summative assessment feedback to the students. Currently, the greatest attention is on assessing effectiveness of e-learning systems within HEIs [1].

Although e-learning has become a household word amongst many academics in Universities from both developed and developing countries, there is still inadequate research focusing on the development of a comprehensive model to define, assess and measure the effectiveness of blended e-learning so as to deal with the aforementioned challenges. In Gunga it is argued that e-learning developers and practitioners are preoccupied with advancing e-learning technologies towards desired quality of e-learning systems rather than providing leverage to the teaching and learning processes [7]. However, there are limited studies focusing on the development of an holistic solution for supporting higher education institutions promoting student-centered learning in the current blended learning strategies. To ensure effective blended learning, we propose a framework that focuses on having a well balanced mix of effective pedagogy in e-learning course design and delivery, apt institutional readiness for e-learning and use of quality e-learning systems to meet institutional and student learning goals. These are important aspects of supporting teachers to promote effective use of e-learning technologies to foster student- centered learning. In the long-run, the framework will be used as a tool to inform decisions made by policy makers, Universities and Governments thus influencing an increase in; rate of graduation, student retention, enrolment levels, return on investment, institutional recognition, and academic achievement as well as improving the performance and quality of teachers, research and education [10].

\section{E-Learning and Effectiveness of Blended Learning within HEIs}

In a University consisting of undergraduate degree programmes, postgraduate programmes such as Certificates, Diplomas, Taught Masters, Masters by research, and $\mathrm{PhD}$ degrees, typical stakeholders of e-learning include: Students, E-learning experts, E-learning system developers, learning technologists, and Lecturers [3]. In Namahn, e-learning systems architecture offers a view of all design elements and functions such as functionality, usability and aesthetics that ought to be integrated in any elearning system [13]. This is a prerequisite of any system development team to engage adequately in requirements elicitation and analysis for the intended system in order to identify its processes, functionality, interface and benefits. Systems design also being a vital aspect of system development must ensure that the predominant principles of system design are followed. In Namahn, these principles are listed as; open architecture, scalability, global, integration, flexibility, rapidness and timeliness [13].

An e-learning framework comprising eight dimensions was developed and described in Khan namely; pedagogical, technological, interface design, evaluation, management, institutional, resource support, and ethical shown in Table 1 [9]. This elearning framework offers a platform that enhances the success of the learner's experience once completely embraced by higher education institutions.

\subsection{Blended Learning}

Blended learning is defined as a combination of online learning and face-to-face instruction [15]. In Driscoll blended learning is defined using four concepts, namely [6];

- Mixing different types of web-based technologies such as collaborative learning, self-paced learning and virtual classroom to achieve educational goals.

- Combining pedagogical approaches and learning theories such as cognitivism and 
constructivism to enhance the learning outcome.

- Combining any type of instructional technology e.g. CD-ROMs, online course material with face-to-face instruction.

- Mixing instructional technology with the practical job tasks.

Blended e-learning takes the form of face-to-face learning with either an asynchronous learning or synchronous learning environment such as live virtual classrooms and discussion forums [18]. On the other hand, e-learning also known as computer-based training, web-based training, technology-based instruction, online learning, and technology enhanced learning is defined as the use of technology to support and enhance learning practice for better learning outcomes [5] [11].

E-learning widely offers a medium that enables learners, instructors and content developers to exchange and share information/knowledge through applications and processes such as internet technologies, Computers, Web technologies, social networks and new instructional technologies [13]. E-learning scholars have commonly categorized e-learning modes of delivery based on the criteria of time and place [5]. Some of these modes of delivery include the following: Use of technology such as internet, CD-ROM, interactive multimedia, games/simulations, and social networks, to enhance the learning process; online instruction for distance learning, blended instruction, synchronous learning often real-time, with multiple instructor-led learners online; asynchronous learning inclined to learners and instructors being in sporadic interaction; instructor-led group work that combines both synchronous and asynchronous learning events; self-study through online tutorials, research and discovery of learning events; self-study with the guidance of an expert in the field of study such as a mentor, coach or tutor; computer-based and web-based tutorials that are individual or group work-centered using online-based self-paced resources.

In Driscoll it is observed that the scope of elearning covers instructional technologies and methodologies such as instructional design and best practices like blended learning, personalization and collaboration; and social networks through social dynamics, cultures and relationships that have supported learning [6].

Blended learning has become popular in many institutions of higher education, especially in countries that have adopted e-learning as a way to facilitate distance education [15] [18]. E-learning is also considered a tool for making effective assessment of learning outcomes and a cost-effective way to allow distant students to have access to learning rather than thinking of it as a tool for gaining deeper understanding of a concept(s) [11]. It is evident that e-learning tools enhance the instructional ability of teachers and learning activities of students, resulting in the improvement of the traditional classroom-based learning hence promoting student-centered learning in higher education institutions [15].

\subsection{Student-Centered Learning}

E-learning technologies are encountered regularly by both teachers and students [17]. The traditional learning is often referred to as teacher-centered learning while the blended learning that offers a mix of traditional learning and use of e-learning technologies is known as student-centered learning [12]. Due to the increased range of e-learning technologies, it's now rare for a course or programme not to be supported by one or more e-learning system [5]. The term student-centered learning has now caught the attention of Universities because no University can exist without students and students will be attracted by effective learning and quality of education within the institutions [7]. Moreover, effective learning has predominantly become the main objective in higher education institutions' Teaching, Learning and Assessment Policy and Strategy.

In the light of this, attention must be given to defining and understanding the meaning of studentcentered Learning and think about what role(s) the teachers ought to play in implementing and using e-learning technologies to foster a good student experience [17]. It is recognized that students learn in different ways and have different learning styles [5]. Students construct their own meaning by talking, listening, writing, reading, and reflecting on content, ideas, issues and concerns. This helps to foster creativity in students. Student learning is recognized as a dynamic process in which students continually create connections between facts, ideas and processes. Such connections are fostered through dialogue between teacher and students, and students with their peers making student-centered learning a highly social initiative that requires constant development of human relationships and communication [16]. Students are supported in making sense of their learning journey through knowledge construction. Constructive and continuous feedback is paramount here. Teachers offer the necessary support to students to develop self-assessment skills. 


\subsection{Evaluation of E-Learning in HEIs}

In their empirical investigation, Ozkan sought to validate their methodological framework, focused on measurement of students' perceived satisfaction with the learning management system in higher education context relative to six dimensions of the hexagonal model [14]. The hexadecimal e-learning assessment model included dimensions namely; service quality, system quality, content quality, learner perspective, instructor attitude and supportive issues. Their results showed that there was a close relationship between students' perceived satisfaction and each of the six dimensions of the Hexagonal model. In Antonis, a learning design methodology was proposed, focused on the design, development and evaluation of distance-learning services that are webbased learning design for adult computer science courses [2]. The framework was based on three main evaluation axes, namely; (1) Information and support provided to learners at the beginning of and during their studies, (2) the learner's performance and (3) the learner's satisfaction. The results showed that the tutors' presence played a significant role in extending support towards the students' accomplishment of the web-based course because of the pedagogical approach to support students. Students judged their satisfaction with the web-based course design on the basis of: enjoyment, benefits, content, adequacy and applicability. In this case, the students were satisfied with the web-based course which greatly impacted on their performance. The students' perceived performance was high as they had great expectations to acquire knowledge and skills, although they were challenged with maintaining their motivation.

As a result, variables were identified from these frameworks to guide the process of developing the proposed framework for evaluating the effectiveness of blended e-learning.

\section{Study Approach}

An expert evaluation survey was conducted to confirm the components to be included the framework. A total of 16 experts were contacted from Universities in Europe, Africa and Asia. Among these were Assistant lecturers, Lecturers, Senior lecturers, Professors, E-learning experts and E-learning developers, later categorized as e-learning educationalist or e-learning technologist as shown in figure. Their experiences were taken based on their use of ICT and web technologies within Universities. These experts were required to rate the importance of each of the factors for effective blended e-learning.

The results in Figure 1 show that majority of the e-learning educationalists had an experience of over
15 years of using ICT and web technologies. On the other hand, the greatest number of e-learning technologies had between $6-10$ years of experience in using ICT and web technologies. In all, the experts had a vast amount of experience in using ICT and web technologies and therefore their opinions were well informed and knowledge-based.

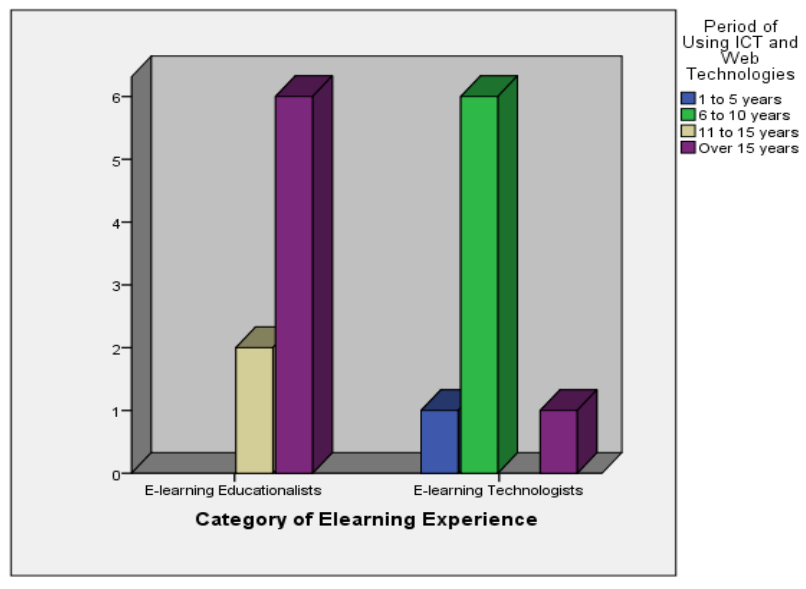

Figure 1. E-learning Expert Experience in the use of ICT and Web Technologies

\section{Framework for Evaluating the Effectiveness of Blended E-Learning}

The established theories, models, frameworks and prior research findings, have influenced the development of the framework which suggests that effective blended e-learning can be achieved by four main dimensions, namely E-learning Readiness, E-learning Course Delivery Strategies, Quality E-learning Systems and Effects of Blended Elearning.

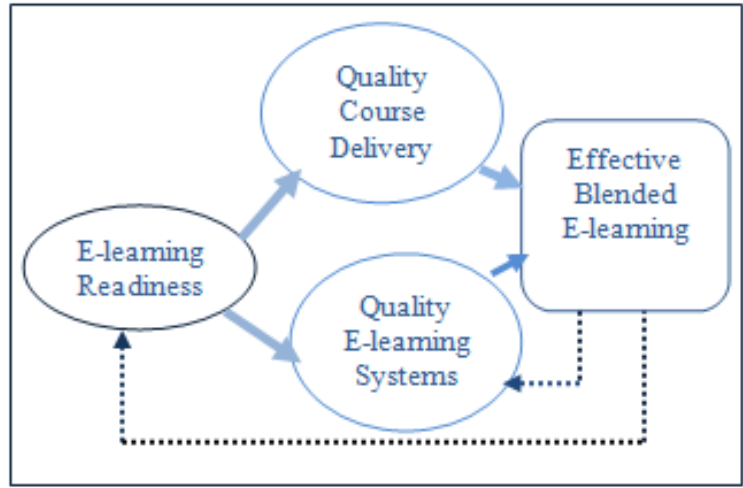

Figure 2. Proposed Framework for Evaluating the Effectiveness of Blended E-Learning Within Universities 
The interactions between these dimensions are illustrated in Figure 2. E-learning Readiness in terms of costing and budgeting, policies, support, cultural awareness, and infrastructure have an influence on the quality of e-learning systems and e-learning course delivery strategies.

The aim of the proposed framework is to aid; understanding of factors influencing the effectiveness of blended e-learning and measure the level of effectiveness of blended e-learning in Universities. The relationship between the dimensions, components in the framework are shown in Table 2. A total of 67 items were created, with 23 items for Course Module Design Strategies dimension, 24 items for E-learning Readiness dimension, 15 items for Quality E-learning Systems dimension, and 7 items for Effective Blended E-learning.

Table 1. A Synthesized List Of Dimensions, Components And Items For Measuring For Assessing E-Learning Readiness, E-Learning Course Delivery Strategies, Quality Of ELearning System And Effective Blended ELearning

\begin{tabular}{|c|c|c|}
\hline Dimension & Component & Item \\
\hline \multirow{23}{*}{$\begin{array}{l}\text { E-learning } \\
\text { Course } \\
\text { Delivery } \\
\text { Strategies }\end{array}$} & \multirow{6}{*}{$\begin{array}{l}\text { Course Module } \\
\text { Layout }\end{array}$} & Course module outline \\
\hline & & Course module prior knowledge \\
\hline & & Course module understandable \\
\hline & & $\begin{array}{l}\text { Course module progression } \\
\text { levels }\end{array}$ \\
\hline & & $\begin{array}{lll}\begin{array}{l}\text { Course } \\
\text { outcomes }\end{array} & \text { module } & \text { learning } \\
\end{array}$ \\
\hline & & Course sequentially organised \\
\hline & \multirow{7}{*}{$\begin{array}{l}\text { Course Module } \\
\text { Evaluation }\end{array}$} & Course module alignment \\
\hline & & Course module requirements \\
\hline & & Course module periodic updates \\
\hline & & Course module resources \\
\hline & & Course module expectations \\
\hline & & Course module difficulty \\
\hline & & Course module teaching quality \\
\hline & \multirow{4}{*}{$\begin{array}{l}\text { Student } \\
\text { Assessment }\end{array}$} & Randomised online assessments \\
\hline & & $\begin{array}{l}\begin{array}{l}\text { Knowledge of } \\
\text { criteria }\end{array} \\
\end{array}$ \\
\hline & & Constructive feedback \\
\hline & & Grading policy \\
\hline & \multirow{6}{*}{$\begin{array}{l}\text { Course Module } \\
\text { Planning }\end{array}$} & Student Learning needs analysis \\
\hline & & Course resource analysis \\
\hline & & Instructional strategies \\
\hline & & $\begin{array}{lll}\begin{array}{l}\text { Course } \\
\text { materials }\end{array} & \text { module } & \text { learning } \\
\end{array}$ \\
\hline & & Student enjoyment \\
\hline & & Learning media analysis \\
\hline \multirow{6}{*}{$\begin{array}{l}\text { E-Learning } \\
\text { Readiness }\end{array}$} & \multirow{4}{*}{$\begin{array}{l}\text { Institutional } \\
\text { Policies }\end{array}$} & $\begin{array}{l}\text { University vision to integrate e- } \\
\text { learning }\end{array}$ \\
\hline & & $\begin{array}{l}\text { ICT Policies on e-learning staff } \\
\text { representatives }\end{array}$ \\
\hline & & $\begin{array}{l}\text { Staff mentoring on e-learning } \\
\text { use }\end{array}$ \\
\hline & & E-learning special funds \\
\hline & \multirow[b]{2}{*}{ E-learning } & $\begin{array}{l}\text { Beliefs about the value of e- } \\
\text { learning }\end{array}$ \\
\hline & & Attitudes towards e-learning \\
\hline
\end{tabular}

\begin{tabular}{|c|c|c|}
\hline & \multirow[t]{2}{*}{$\begin{array}{l}\text { Culture } \\
\text { Awareness }\end{array}$} & $\begin{array}{l}\text { Academic achievement with e- } \\
\text { learning }\end{array}$ \\
\hline & & Societal norms on e-learning \\
\hline & \multirow{4}{*}{$\begin{array}{l}\text { E-learning } \\
\text { Infrastructure }\end{array}$} & $\begin{array}{ll}\text { Access to computing } \\
\text { technologies }\end{array}$ \\
\hline & & $\begin{array}{lll}\begin{array}{l}\text { Tools for } \\
\text { development }\end{array} & \text { course module } \\
\end{array}$ \\
\hline & & $\begin{array}{l}\text { Up-to-date system platforms for } \\
\text { course module delivery }\end{array}$ \\
\hline & & $\begin{array}{lll}\begin{array}{l}\text { Lecture } \\
\text { system }\end{array} & \text { recording } & \text { capture } \\
\end{array}$ \\
\hline & \multirow{4}{*}{$\begin{array}{l}\text { E-learning } \\
\text { Costs }\end{array}$} & $\begin{array}{l}\text { Cost of development of course } \\
\text { module material }\end{array}$ \\
\hline & & $\begin{array}{l}\text { Cost of implementing e-learning } \\
\text { systems }\end{array}$ \\
\hline & & $\begin{array}{l}\text { Cost of maintaining e-learning } \\
\text { platforms }\end{array}$ \\
\hline & & $\begin{array}{l}\text { Cost of technical and e-learning } \\
\text { support }\end{array}$ \\
\hline & \multirow{6}{*}{$\begin{array}{l}\text { E-learning } \\
\text { Support }\end{array}$} & E-learning induction training \\
\hline & & $\begin{array}{l}\text { Course module development } \\
\text { support }\end{array}$ \\
\hline & & On-demand support \\
\hline & & $\begin{array}{l}\text { Staff capacity development on } \\
\text { use of e-learning }\end{array}$ \\
\hline & & E-learning staff webinars \\
\hline & & ICT training support \\
\hline \multirow{15}{*}{$\begin{array}{l}\text { Quality } \\
\text { E-learning } \\
\text { Systems }\end{array}$} & \multirow{11}{*}{$\begin{array}{l}\text { E-learning } \\
\text { Management } \\
\text { System Design }\end{array}$} & $\begin{array}{l}\text { Adaptability of course module } \\
\text { platform }\end{array}$ \\
\hline & & Ease of navigation \\
\hline & & $\begin{array}{l}\text { Consistency of course module } \\
\text { platform }\end{array}$ \\
\hline & & User-friendliness \\
\hline & & Multi-culturally appealing \\
\hline & & $\begin{array}{l}\text { Accessibility of course module } \\
\text { content }\end{array}$ \\
\hline & & Event management \\
\hline & & User management \\
\hline & & Security of user data \\
\hline & & Collaborative learning \\
\hline & & Interactive learning \\
\hline & \multirow{4}{*}{$\begin{array}{l}\text { Student } \\
\text { Learning } \\
\text { Management }\end{array}$} & Student tracking \\
\hline & & Time management \\
\hline & & Learning tracking \\
\hline & & Use of e-portfolios \\
\hline \multirow{6}{*}{$\begin{array}{l}\text { Effective } \\
\text { Blended } \\
\text { E-Learning }\end{array}$} & & Student retention \\
\hline & & Student access to learning \\
\hline & & Cost effectiveness \\
\hline & & $\begin{array}{l}\text { Performance and quality of } \\
\text { lecturers }\end{array}$ \\
\hline & & Academic achievement \\
\hline & & $\begin{array}{l}\text { Improvement of research and } \\
\text { education }\end{array}$ \\
\hline
\end{tabular}

\section{Effectively Using E-Learning Technologies to Promote Student-Centered Learning}

Several researchers have discussed different ways to measure the effectiveness of any learning intervention. In Khan, factors that positively influence the effectiveness of blended e-learning were mentioned [9]. From both literature and revelations made by the e-learning experts, the following factors are important namely; student 
characteristics, e-learning benefits awareness, prior e-learning experience, and interactive discussions.

\subsection{Student Characteristics}

It is believed that some learners are likely to make an effective use of e-learning mainly influenced by their age, gender, and level of education. These attributes are positively related to the effectiveness of blended e-learning.

\subsection{E-Learning Benefits Awareness}

Prior research studies show that perceived benefits of using e-learning amongst students and lecturers will foster the effectiveness of blended e-learning. Such benefits are related to gaining access to student material, academic achievement, improvement in the quality of research and education, improvement of performance of the University. As one expert is quoted;

Expert 3: "Focus should not be on who should handle the system...but what's the benefit we get for the institution and for the lecturers, both should benefit, the institution should get income and also lecturers get more income",

Furthermore, for some students especially the mature professional and part-time students, blended e-learning enables them to combine work and education.

Expert 4: "So, to benefit students from deprived cities, they opened distance learning programs to extend education as well as empower the less privileged remote Universities. At the end, e-learning is used to support the distance learning, without necessarily opening up other campuses."

\subsection{Prior E-Learning Experiences}

Whenever students or lecturers are confronted with a new learning environment, there is a tendency of fear cropping in, leading to negative attitudes. This is common amongst students and lecturers who are novice ICT users. There is a likelihood of such user experiencing great difficulties with new learning systems. The more experienced the students and lecturers are, the more confident they are with using e-learning systems. Prior e-learning experiences are positively related to the effectiveness of blended e-learning.

\subsection{Interactive Discussions}

With the current blended e-learning initiatives, all kinds of students can be supported by giving them access to e-learning course material by offering a blend of asynchronous (self-paced) e-learning, synchronous (live virtual) e-learning and face-to-face consultations. In this case, all kinds of students, thus; full-time, part-time and distance learning students are supported. This enables engagement of students, which makes them feel part of the course. These interactive consultations are offered through live chats, discussion threads, group-work, and real-time class meetings through face-to-face and whiteboards [5]. Four of the five Experts agreed that their e-learning systems were mainly used to support part-time and distance learning students.

An expert was quoted saying:

Expert 3: "Most of the distance learning does not offer face-to-face, but we ensure quality of the student's learning by providing online live consultations as well as collaborative discussions where so many students can participate in the discussions. We also provide students with very good course material, so that it is easy for them to read it and understand while at home. But also...e-learning can make regular education to become fun"

Therefore, to complement traditional face-to-face classroom learning, both asynchronous and synchronous e-learning have been adopted by many traditional Universities to reach more students seeking University education as well enhance the effectiveness of course programs.

\section{Discussion}

On average, the e-learning educationalists agreed more to the factors in the framework $(M=3.5287$, $\mathrm{SE}=.1612$ ) than the e-learning technologists $(\mathrm{M}=3.1086, \mathrm{SE}=.05644)$. The difference was not significant $\mathrm{t}(14)=2.45$, p. $>.05$. as shown in Table 2 and 3 .

The advances in e-learning and web technologies have enabled the provision of higher education to students namely; full-time, professional, distance and part-time students. The study results and findings indicate that e-learning in blended learning environments can be made effective by focusing on three constructs, namely; quality of course design, e-learning readiness and quality of e-learning systems. The factors influencing effective blended e-learning have been identified basing on existing theories and models for assessing the success of learning interventions and systems. These factors include: course content, course evaluation, course planning and development, assessment and feedback, e-learning support, e-learning policies, e-learning culture, e-learning infrastructure, e-learning costs, quality LMS systems, quality service delivery, student characteristics, e-learning benefits awareness, 
prior experience in e-learning, and interactive discussions.

Table 2. Independent Sample Test Means

\begin{tabular}{rrrrrr}
\hline $\begin{array}{r}\text { Category of Elearning } \\
\text { Experience }\end{array}$ & N & Mean & $\begin{array}{r}\text { Std. } \\
\text { Deviation }\end{array}$ & $\begin{array}{r}\text { Std. Error } \\
\text { Mean }\end{array}$ \\
& & & & & \\
\hline $\begin{array}{r}\text { Factors for Effective } \\
\text { Blended E-learning }\end{array}$ & $\begin{array}{r}\text { E-learning } \\
\text { Educationalists }\end{array}$ & 8 & 3.5287 & .45597 & .16121 \\
& $\begin{array}{r}\text { E-learning } \\
\text { Technologists }\end{array}$ & 8 & 3.1086 & .15965 & .05644 \\
\hline
\end{tabular}

Table 3. Independent Sample T-Test

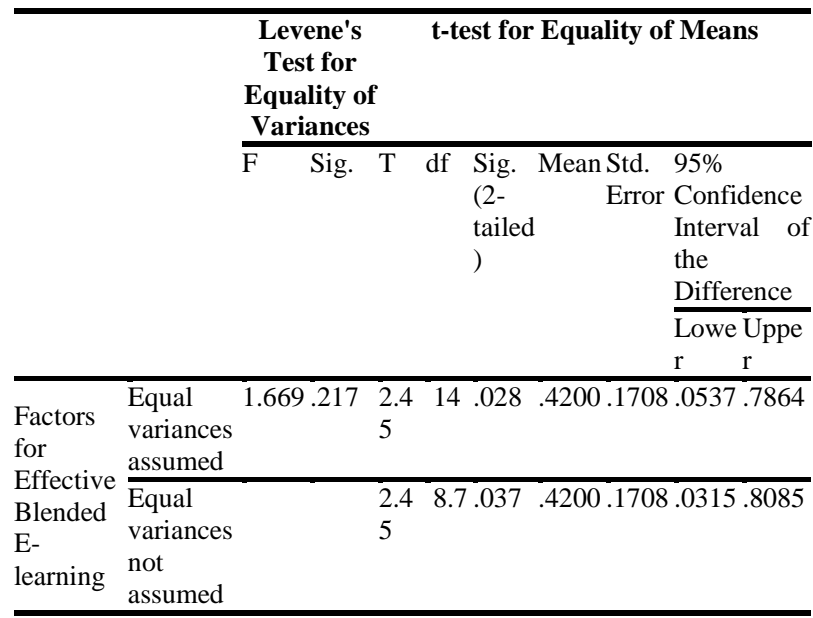

\section{Conclusion}

The main challenge for HEIs is to find a model that can used to facilitate effective use of e-learning technologies to enhance blended learning within Universities to promote student-centered learning. In a bid to address this challenge, an expert study was initially conducted to understand the factors that impact on the effectiveness of blended e-learning within Universities. The framework in this paper was used as an instrument to conduct an explorative study to understand factors that influence effective use of e-learning technologies to promote student-centered learning paradigms within Universities. The research study revealed gaps both in the existing literature and University working practices, regarding the blended e-learning needs of staff and students. The theoretical model developed provides a holistic approach to planning and implementing blended e-learning initiatives within Universities effectively. The theoretical model was developed based on existing theories, models and opinions from both e-learning educationalists and e-learning technologists. The exploratory study focused on discovering factors that enable, support and enhance the effectiveness of blended e-learning within Universities. Research clearly shows that e-learning implementation needs to go through a systematic planning, development process. It is on this premise that the theoretical model systematically integrates factors deemed important for facilitating effective blended e-learning within Universities. The theoretical model helps to answer the research question posed "What are the important factors that influence the effectiveness of blended e-learning within Universities to foster student-centered learning?"

The survey was carried out to help understand how the use of e-learning technologies complements existing traditional face-to-face teaching methods. The study established that both e-learning educationalists and e-learning technologists attributed importance to the quality of course design, an institution's e-learning readiness, quality of e-learning systems, online consultations, and support to course planning and development process and evaluation of courses. Therefore, these factors were considered very important for planning and implementing blended e-learning initiatives as they facilitate delivery of quality content and effective course design.

\section{References}

[1] Andersson, A. (2008). Seven major challenges for elearning in developing countries: case study eBIT, Sri Lanka. International Journal of Education and Development using Information and Communication Technology, 4 (3), pp. 45-62.

[2] Antonis, K., Daradoumis, T., Papadakis, S. and Simos, C. (2011). Evaluation of the Effectiveness of a Web-based Learning Design for Adult Computer Science Courses. IEEE Transactions on Education, 54 (3), 374-380.

[3] Arabasz, P., Pirani, J. A. and Fawcett, D. (2003). Supporting E-Learning in Higher Education. EDUCAUSE Center for Applied Research.

[4] Britain, S. \& Liber, O. (2003). A Framework for the Pedagogical Evaluation of Virtual Learning Environments. JISC. UK.

[5] Clark, R. C. and Mayer, R. E. (2003). e-learning and the science of Instruction: Proven Guidelines for Consumers and Designers of Multimedia Learning., San Francisco, CA, John Wiley \& Sons, Inc.

[6] Driscoll, M. (2002). Blended Learning: Let's Get Beyond the Hype. Available: http://www07.ibm.com/services/pdf/blended_learning.pdf [Accessed 20th December, 2011].

[7] Gunga, S. O. and Rickets, I. W. (2007). Facing the Challenges of E-learning Initiatives in African Universities. 
British Journal of Educational Technology, 38 (5), pp. 896906.

[8] Hughes, J., Katzeff, C., Abdallah, L., Scheuermann, F., Reich, K., Admiraal, W., . . . Kuusinen, R. (2006). Evaluating E-learning. A Guide to the Evaluation of Elearning, Stanford, California, Creative Commons.

[9] Khan, B. H. (2010). The Global Elearning Framework. Elearning.

http://webserver.ignou.ac.in/institute/STRIDE_Hb8_webC

D/Chapter\%205.pdf.

[10] Kirkpartick, D. L. (1994). Evaluating Training Programs, San Francisco, Berrett-Koehler Publishers, Inc.

[11] Mayes, T. and De Freitas, S. (2005). JISC e-Learning Models Desk Study. Stage 2: Review of e-Learning theories, frameworks and Models Joint Information Systems Committee.

[12] Motteram, G. (2005). Blended Education and the Transformation of teachers: a long-term case study in postgraduate UK Higher Education. British Journal of Educational Technology, 37 ( 1), pp .17-30.

[13] Namahn. (2010). E-learning. Available: http://www.namahn.com/resources/documents/note-elearning.pdf [Accessed 27th April, 2012].

[14] Ozkan, S. and Koseler, R. (2009). Multi-Dimensional Evaluation of E-Learning Systems in the Higher Education Context: An Empirical Investigation of a Computer Literacy Course.ASEE/IEEE Frontiers in Education, 2009. San Antonio, TX. IEEE.

[15] Rosenberg, M. J. (2006). Beyond E-Learning: Approaches and Technologies to Enhance Organizational Knowledge, Learning, and Performance, John Wiley \& Sons, Inc. USA, Pfeiffer.

[16] Selwyn, N. (2014). distrusting educational technology: critical questions for changing times. New York, Routledge, Taylor \& Francis Group.

[17] Selwyn, N. (2014). Digital Technology and the Contemporary University: DEGREES OF DIGITIZATION. Society for Research into Higher Education. New York, Routledge, Taylor \& Francis Group. [18] Sharpe, R., Benfield, G., Roberts, G. \& Francis, R. (2006). The undergraduate experience of blended elearning: a review of UK literature and practice. Oxford, United Kingdom: The Higher Education Academy

[19] Ssekakubo, G., Suleman, H. and Marsden, G. (2011). Issues of Adoption: Have E-Learning Management Systems Fulfilled their Potential in Developing Countries? SAICSIT, 231-238.

[20] UNESCO (2006). Teachers and Educational Quality: Monitoring Global Needs for 2015. UNESCO Institute for Statistics, Montreal. http://unesdoc.unesco.org/images /0014/001457/145754e.pdf. 